\title{
Special topic: strategic innovations
}

\author{
Kai-Ingo Voigt
}

Published online: 8 July 2011

(C) Springer-Verlag 2011

Strategic innovations “... pose radically different challenges for established firms and have radically different implications for managers" (Markides 2006 p. 19). The discussion about strategic innovations started in the 1990s, as Christensen (1997) developed his theory about disruptive innovation. The theory focuses on innovations which offer a new set of attributes to create higher customer benefit compared to established technologies. Established firms, or respectively "incumbents", often neglect these kinds of innovations and show mal-adaptive reactions upon this challenge. Thus, established firms may find themselves within a dilemma, because they struggle to manage the switch from an "old" to a "new" technology and cannot make both coexist in the same organization (Markides 2006), even when the innovation is already adopted by the (newly created) market. Within the concept of disruptive innovation, Christensen and Raynor (2003) have further defined the two terms "low-end disruptions" and "new-market disruptions". Hereby, new-market disruptions are creating an entire new market and simultaneously offer a novel set of product performance. In contrast, low-end disruptions are innovations which are less expensive and often provide a quality lower than the industry standard.

In a much broader sense, strategic innovations also comprise business model innovations (Chesbrough 2007). Business models determine the way of doing business in companies. The term "business model" is commonly used in daily business and is, almost as a buzzword, omnipresent in political or cultural discussions. The term itself has its origin in the spread of E-Commerce between 1996 and 2000. The main question in this field is how to create sustainable and innovative business concepts by changing the configuration of the business model building blocks (Osterwalder and Pigneur 2010). In addition to that, existing firms

K.-I. Voigt $(\square)$

School of Business and Economics, University of Erlangen-Nuremberg,

Lange Gasse 20, 90403 Nuremberg, Germany

e-mail: voigt@industrial-management.org 
are typically confronted with the problem of how to transform an existing business model successfully.

The following two papers are primarily focused on the topic of disruptive innovation. The paper by Reinhardt and Gurtner assumes that an essential part of creating disruptive innovations is gathering the right information about potential and current customers. Several methods for customer analysis are considered and integrated in this paper. The authors summarize the results of a literature review on customer analysis' requirements for disruptive innovations. In addition to that, they propose a coherent model that points up the information needed to successfully shape the disruptive innovation process. Thus, they present a systematic approach, how a combination for customer analysis methods should be laid out to contribute to a better anticipation of future customer needs.

The second paper by Bockmühl, König, Enders, Hungenberg and Puck deals with the incumbent's response to technological change. The authors develop a model of incumbent response by integrating different concepts and scientific results in this field. In a second step, they systemize the variables that determine the course of action of the incumbents. Thereby they consider the three constructs of "identification and interpretation", "decision making" and "organizational implementation". The model is tested empirically in the German dental lab industry. The authors are able to show the impact of the selected items on timeliness and intensity of response by using structural equation modeling. The results also show how timeliness and response intensity affect business performance in new technological domains.

Both papers which are presented here contribute significantly to scientific progress in the field of strategic innovations. They provide a deeper understanding of the mechanisms behind disruptive innovations and additionally allow to derive some useful managerial implications.

\section{References}

Chesbrough H (2007) Business model innovation: it's not just about technology anymore. Strategy Leadersh 35(6):12-17

Christensen CM (1997) The innovator's Dilemma: when new technologies cause great firms to fail. Harvard Business School Press, Boston

Christensen CM, Raynor ME (2003) The innovator's solution: creating and sustaining successful growth. Harvard Business School Press, Boston

Markides C (2006) Disruptive innovation: in need of better theory. J Prod Innov Manag 23:19-25

Osterwalder A, Pigneur Y (2010) Business model generation. Wiley, Hoboken 